\title{
Bamian Bound:
}

\section{Salam Mission}

\author{
Report
}

$$
\text { May } 29 \text { - June } 19,1990
$$

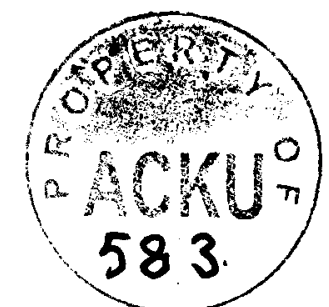




\section{Contents}

Bamian Bound

Salan Mission to Banian

1. Introduction 1

1.1 Bamian 1

1.2 The Local situation 2

1.3 Mission Achievements 4

1.3 Security 5

2. The Population and Food Sufficiency 6

$\begin{array}{lll}\text { 3. Food Ald } & 8\end{array}$

4. Logistics 9

5. Health 13

$\begin{array}{lr}\text { 6. Historic Sites } & 17\end{array}$

7. Other Fields 19

$\begin{array}{ll}7.1 \text { Agriculture } & 19\end{array}$

7.2 Animal Health 21

7.3 llines 21

7.4 Mine Awarenes $\quad 22$

8. Some Conclusions 22

List of participants

List of Comittees established by Bamian Islamic Shura Map

List of Annexes 


\section{Introduction}

This report 18 of the first United Nations international mission to Bamian province. Separate information 18 avallable from ission participants on detalls relevant to their specific fields of activity: Health, Food $A 1 d, L o g 18 t 1 c s$ and Historic sites.

\subsection{Banlan}

Banian is a knot at the centre of Afghanistan, drawing together strategic routes which thread their way through the Hindu Kush from north to south and east to west. To the north are roads and tracks to Baghlan, Mazar-1-sharif and the pastures of the northern provinces; to the south and south east, over the Hafl Gak Pass, 1s Wardak, Ghazn1, plains and Pakistan, to the east are Parwan and the bazaars of Kabul, even today only one day's travel away, and to the west is the vastness of rural Hazarajat, the promise of Herat and eventually Iran.

One experienced traveller has singled out Banian as symblotc for five reasons: it is at the centre of the country; it contains some of the most important historic monuments in Asia; it is the scene of religious cohabitation; of ethnic cohabitation; and lastly, its provincial capital was the first to fall under mujahedin control. The UN mision found the local authorities to be very aware of each.

The Buddhas of Bamian and Genghis Khan's awesome legacy in the ruins of the Whispering city are tribute to the area's strateglc and logistical importance. Yet the valley 18 remote and seemingly landlocked, within an already landlocked country, for months at a time, natural and political hazards taking their turn to 1801 ate the area from the outside world.

Central Afghanistan has for centuries been poor, particularly to the west and south west, the Hazarajat. Notwithstanding, this brief UN mision was unprepared for the deprivation that, beyond the hospitality, it glimpsed. While only limited areas have been directly affected by fighting (Bamian Town 1 tself being largely wrecked), the lifeblood of the area has been throttled by gradual degrees as the war has ground on. 
Initial assessments indicate that up to 208 of the population in certaln parts of central Afghanistan are elther internally displaced or refugees, elther In Kabul, Iran or, less frequently, Pakistan. Conversely, groups have moved to the area in the last 10 years from the cities or from the north.

Central Afghanistan will be a source of futher refugees and internally displaced. It has always been an area of emigration. However, 10 years of war, lack of access to relief and development resources, biting winters, and vulnerability to natural disasters have conspired to reduce the population, particularly in the Hazarafat, to a level of poverty that may be unmatched in central Asta.

At a time when Bamian and central Afghanistan has been peaceful for almost two years, UN particlpants could not but contrast the attention and assistance currently being afforded to 'refugee return' areas with the relative lack of commitment to the area visited.

\subsection{The local situation}

The relations between the various groups which occupy central Afghanistan are beyond the scope of this report.

Suffice it to say that Bamian centre contains 8 political parties, each represented on the Islamic, military, shura. The Shura has been the principal local authority since the mujahedin took control of Bamian town in late 1988 .

Three are shia parties (Harakat Islaml (Mohsent), Nasr and Sepah); three technically belong to the Interim Government in Peshawar and, In their local manifestation, are sunnt and Tafik (Harakat Inqelab, Jamiat Islami and Mahaz-1-M1111); another, llezbi tislami (Hekmatyar) has a simflar following but is locally led by a Pashtoon and 18 outside the AIG; and the elgth, Jabha e Mustazafin, has no tribal or ethnic.identity, being a small local party with a dedicated and educated membership. 
The authority of the Islamic shura of Banian does not extend beyond Bamian centre. Arrangements made with the shura do not therefore necessartly hold elsewhere. However, as the natural focal point of Bamian province and points further west, developments in Bamian town are closely watched throughout the area. The mission impressed upon the Islanic shura the signiffcance for the whole area of the un having a productive relationship with the shura. This was well understood.

The mission was repeatedly asked by one of the parties, the Hustazafin, to meet with the 'Elders' shura' of Bamian. One participant did so. However, as elsewhere in Afghanistan, any effort to establish local civilian and technical counterparts can only succeed with the blessing of local military authorities. Leaders of several parties expressed their reservations, even antipathy, towards the Elders' shura.

To the west of Bamlan, the new alliance of Shla parties, Hezbl Wa'adat, clatms pre-eminence; of the shia parties, only Harakat Islami (Hohsent) is not a member, although some local Harakat commanders have chosen to join. The mission met with 8 members of the Central Committee of the Hezbl Wa'adat (see Annex Document) who happened to be present in Bamian town to celebrate the first anniversary of the death of Imam Khomelni. They welcomed cooperation with the UN. There 18 considerable speculation as to whether the Hezbl Wa'adat will succeed in 1 ts alm to represent all Shia interests Ir Afghanistan, and as to the precise origins of the party.

To the east, the social and political geography 18 more complex, with Taftk, Ismatil, and Hazara groups dappled across the country towards Kabul and southern Baghlan. Fighting continues around Kabul, with the whole spectrum of Afghan mujahedin parties represented.

One side effect of this cocktall is that every group in the area feels itself to be in a minority of some kind. This is a recipe for insecurity, and local politics reflect the fact. While Bamian has seen no flghting since late 1988, mutual susplctons have 
Increased as the common threat, GOA presence, has become more remote. The mission experienced the insecurity first hand: the main obstacle to obtaining the school as an office was that it had been 'reserved' for use by Tajik groups as a military base. success in retrieving the bullding for more humanitarian purposes was therefore mozl significant.

In these circumstances the mision was very careful to show 1 ts neutrality and demonstrate 1 ts determination to treat all groups with an even hand. The mision was entertained by 7 of the 8 parties in Bamian town (only sepah did not extend an invitation) and travelled to both Hazara and Tajik strongholds. Only time prevented it from visiting other areas and from visiting other groups.

Participants were struck by the absence of reference to the AIG and the Peshawar scene, even among members of parties belonging to the AIG.

\section{3 llssion achievements}

11 UN staff members travelled for 22 days and $2,975 \mathrm{~km}$ through 7 provinces to and from central Afghanistan. 10 of these days were spent in Bamian province. All returned fit and safely.

The mission established a working relationship with the Islamic Shura of Bamian Town. The UN has been given a temporary office in a secondary school situated at the feet of the smaller of the two big Buddhas. The shura has also provided the UN with a permanent office site on neutral ground which needs to be rehabilitated.

One objective of the trip was to encourage local authorities in Bamian Town to develop a civilian administration. By the time the mission left, the Islamic shura had established elght committees, one each for Agriculture, De-mining, Education, Food-for-work profects, Health, Historic sites, Logistics, and Reconstruction. The mssion was asked to encourage the NGOs henceforward to work through these committees. 
health, logistics, historic sites and food assistance. A mine survey team and demining team were dispatched to Bamian immediately after the mission. More limited information was also gathered $1 n$ the flelds of education, animal health and agriculture.

Inevitably, the presence of a salam mission has ralsed expectations among the local population. No firm commitments were made. However, the visit had been long and eagerly expected; many are now walting to see how the UN will follow 1 t through. Discussions on emergency food needs will in particular have ralsed hopes.

Participants made forays north, south, east and west of Bamian Town and contacted local authorities wherever possible. It 18 important to note that this salam mision was thus not fust to the Hazarafat but, more correctly, to central Afghanistan.

Everywhere the m18sion emphasised the UN'B willingness to work with all those in need, regardless of ethnic or religlous Identity, both in Bamian centre and in areas reachable from Bamian. It repeatedly ephasised that access to uN technical and financial resources depends in large part upon the receptivity of local communities and their willingness to defer political differences to common humanitarian objectives.

\subsection{Security arrangements}

An escort was provided throughout the trip through the peshawar offlces of commander Anwart of Harakat Islami (Mohsent) on the understanding, repeatedly underscored to all interlocutors, that the mision did not 'belong' to Harakat Islami. other parties, for oxample Sazman-1-Nasr and Hezb1 Islami (Hekmatyar) also provided escorts and guides on certain occasions.

Participants felt secure throughout their travels, Increasingly so the further they penetrated Afghanistan. There was only one serlous security incldent: an unruly and excited party of Hezbl Islaml (Hekmatyar) mujahedin delayed the mission for several hours at Daymlrdad, Wardak, choosing to demonstrate 1ts prowess 
by disarming and abusing the escort and by beating up a Harakat Islami (Mohsent) commander who had tried to intercede. Good fortune obviated what might have been a very ugly and dangerous situation.

On the way back from Bamian east of Ghazni the mission was passed by two Government of Afghanistan helicopter gunships. It came across no other overt sign of GOA presence.

The escorts accompanying the trip were armed. This was more of a liablitty than an asset. It would have been more useful to have had a relay of guides, each knowledgeable about local routes and conditions, along the way. The mission found itself escorting the escort rather than being escorted by it on more than one occasion.

\section{The Population and food sufficiency}

A large part of the Hazarajat is within Bamian province in an area which straddles the centre of the country. The food situation 18 not good largely because agricultural land is limited to tiny slopes and valleys between the mountainous areas. Hazarajat was well known as a food deficit area before the war, which itself has obviously not improved the situation.

Before the war the population was estimated at 250,000. From information gathered locally, it would seem that 85 of the population is still present (or approximately 215,000 people). The balance, often young men looking for work, has mostly gone to Iran. Statistics for the whole of the Hazarafat are unavallable but for Bamian province only, food import trends have been recorded by one of the political parties represented in the Islamic shura of Bamian, whose base 18 located at the strategic crossroad of Shashpul. They record the passage of all vehicles and their loads, using a well organised statistical team:

$\begin{array}{lcccc}\text { Imports } & 87 & 88 & 89 & \text { Jan-Mar. } 1990 \\ \text { Wheat (MT) } & 1767 & 2678 & 2900 & 800 \\ \text { Rice (MT) } & 1557 & 3085 & 4300 & 750\end{array}$


Imported goods are mostly from the north and Kabul. Only a trickle comes from Pakistan through Jaghorl and the Hafl Gak pass; periodic fighting, local hostility and roadblocks in Pushtoon areas limit the use of the southern route. The road west of Bamian to Iran has been destroyed between Yakawlang and Chagcharan and 18 therefore Inaccessable by truck.

Bamlan province's exports are potatoes and wooden beams. While 1 t Is almost certain that the animal population, especially sheep, has decreased, some of those met sald that in certain areas at least the cattle population has increased (some sald by a factor of flve over the last four years). However, conditions deteriorate the further west and southwest one goes, Bamian centre 1 tself being perhaps the best off.

Agrlcultural ylelds are low: about an average of 40 seer of wheat per Jertb/year in Yakawlang and Jaghori, about 50 in Bamian centre.

The average family in the area needs about 3 MT, if not more, wheat every year. To grow this amount, each family needs at least 10 Jerlbs of land. Few do. As an Indlcator, according to Hustazafin statistics, Bamian province has about 60,000 ferib of cultivated land (1rrigated and rain-fed). If one assumes a figure of 25,000 to 30,000 families, minfmum land under cultivation to grow enough for self sufficlency would be around 250,000 to 300,000 jer1b.

Bamlan and the area to 1 ts west are very clearly food deficlt areas. Personal incomes are very low. This, combined with successive natural disasters like landslides and floods, makes the population very vulnerable. This year appears to be particularly bad, with good lands belng washed away, the harvest late and, In many parts, poor. 
If no assistance is forthcoming, the number of internally displaced (mostly old men, children and women) and refugees (young men going to Iran) from the area stretching from parwan (which, as the mission repeatedly heard, has suffered heavy floods and loss of agricultural producel to the Hazarajat will increase. Creeping malnutrition among children will also increase as well as the overall mortality rate of the population.

Thus central Afghanistan is distinct from, for example, many areas bordering Pakistan in a number of important ways: it is a food deficit and much poorer area; 85 of the population 18 still present; labour 18 avaliable and cheap (rates range from 500 Afs/day in Yakawlang to $900 / 950$ in Bamian for unskilled labour see Annex Document; the local population and authorities are relatively unfamiliar, and therefore not 'spolled', by foreign assistance; there is great potential for food-for-work projects, both because of lack of development overall and because of the many more immediate problems such as landslides and floods.

\section{Food A1d}

Central Afghanistan might prove to be the best place in the country for food for work; little has been done because of priority accorded to the huge problems in the north and to refugee return areas in the south, as well as because of the inherent logistical difficulties in reaching the centre of the country.

Four WFP projects have been approved in the area and which were monitored during the mission. For detalls, see Annex Document. In future the UN should avold dispatching food to the area without clearly ldentifying implementing partners and the responsibilities of the various parties involved, including the shuras. The Un 18 fortunate that the despatch of 500 MT from Mazar-1-Sharif did not go entirely awry, given the absence of clear arrangements for recelving the wheat and sugar. 
Central $\Lambda$ fghanistan would benefit from a number of food aid projects (sec nnnex Document for three project ideas drawn up during the mission). Care should be exercised to ensure that food ald does not create dependency or erode the determination of the people to help themselves. The creation of a committee to facilitate food-for-work profects is a good step in the right direction. At all times it was explained to those met that food assistance 18 an input to promote profects in any number of flelds.

It must also be hoped that there are no blockages in the provision of funds to pay for the transport of food assistance.

The problems of ensuring the safe delivery of food assistance, especially when dispatched from long distances, will remain and might even worsen. Imaginative approaches are needed and the formulae being used in northern Afghanistan should be reviewed for use in Bamian and the Hazarajat.

Above all, a co-ordinated approach to the provision of food assistance is required; central Afghanistan should not suffer because of lack of communication between UN duty stations.

\section{4. $\log 18 t 1 \mathrm{cs}$}

A glance at the map highlights the importance of Bamian as a logistics centre: to the west its roads connect with Yakawlang, Panjao, Chagcharan and Herat; to the east with shumbul, Sheikh Ali and Kabul; to the north with Saighan, Kamard, Doshi and Mazar-i-sharif; and to the south with Behsud, raizak, Chak, Maidan Shahr, Ghazni, Urgun and Angor Ada.

Bamian deserves consideration as a centre of distribution for a large part of the country, particularly if distribution from points further north becomes problematic. For six months of the year, however, the area south of Bamian is blocked by the snow on the Hajt Gak pass and is more easily reached from pakistan. 
The mission explored a number of issues during its stay:

\subsection{The possibility of establishing a unILOG Base in Banian}

The Islamic Shura has agreed to allow UNILOG to set up a base in Bamian which conforms to UNILOG's requirements (see Annex Document for letter from the Islamic shura). The Shura established a committee for logistics and provided a list of candidates as counterparts from which UNILOG may chose. One of the more promising of these candidates is from the Mustazafin party which already supports transport-related activities, including a workshop, where mechanics repalr their own and other parties' vehicles.

The Shura suggested the airstrip as a location for the uwILoG base and store, but is happy to consider other sites - for example near the bazar. Other possibilities include a) the old Government store, destroyed in late 1988 , on the road towards Shashpul from Bamian bazar; b) the 19 th century caravanseral midway between Shashpul and Bamian town, and cl the Mustazafin workshop near shashpul.

\subsection{Use of GOA held c1t1es for logistics purposes}

In discussions both with the Islamic shura of Bamian and other authorities (for example, representatives of the central Committee of the Hezbi Wa'adat; the shura at Yakawlang), the mission raised the possibility of using Kabul and perhaps Mazar1-Sharif as despatch centres for UN goods to Bamian. Reaction to the idea was almost always positive, as long as any goods were clearly identified as belonging to the UN and the GOA has no part in their transportation. Goods in the bazaars anyway come usually from GOA held cities and so the logic of the UN using the same routes ralsed few eyebrows.

The UN should explore this opportunity. 500 MT of WFP wheat and sugar have already come from Mazar-i-Sharif, with mixed results, and during its stay, the mission requested UNICEF in Kabul to 
send some medecines to southern Baghlan. At the time of writing it is still not clear whether they arrived safely. Further discussions are needed with the relevant commanders who control the access routes to Bamian.

\subsection{The airstrip at Bamian}

The Islamic shura welcomed the ldea of the airstrip being used by the UN to fasilitate its work. It doubted, however, whether the GOA would allow the UN to use the strip. The shura felt that there would be no problem in alerting the mujahedin to the arrival of a UN plane to ensure that it does not become a target.

The strip is in good condition, with the exception of a few small holes and a damp patch. Its surface is hard and mine-free bullding the de-mining team will double check this). The buildings around the strip have been destroyed and the fields around it are mined. The concerns and exact requirements of the pilots of the UN plane should be addressed during the next trip
to Bamian by the UN.

\subsection{Route/Road Conditions}

The misiton travelled approximately $3,000 \mathrm{~km}$ during its three week trip. The route was as follows (вee map):

Peshawar-Wana-Angor Ada-Urgun-Sharan-Zarghun-
Shahr-Qarabagh-Nawur-Taizak-Bamian-(Yakawlang, Sheikh Al1, Tala, Barfak) - Tizak-Chak-Sayedabad-Ramak-Zormat-Sarawza-Sultan1-Chahrba ran-Rabat-Angor Ada-Wana-Peshawar.

See Annex Document for further detalls of the route, information on the availability of fuel, mechanics, spare parts and storage,
etc.

Unsurprisingly, the roads are very poor, having been damaged both by fighting in some areas and through neglect. It is remarkable that some roads have survived ten years of little or no 
maintenance and regular flooding. The mission repeatedly came across locals and truck drivers repairing the roads with shovels and with whatever means were immediately available - wood, stones and bits of scrap. Children and adults often expect passing vehicles to contribute small sums for their ad hoc road and bridge maintenance efforts.

\subsection{Security for transport}

Security in central Afghanistan, particularly the Hazarajat, is generally considered to be better than in areas to the south; the mission's experience confirmed this. Because of tensions between Hazara and Pashtoons, any escorts for aid shipments should be carefully selected, especially in border areas between the groups. It must be hoped that the Islamic Shura in Bamian and its committee responsible for logistics will help with security measures but 1 ts writ beyond Bamian will be very limited, even with other groups from the same parties.

It would make sense for UNILOG convoys to Bamian to proceed by the shortest route through pashtoon areas, for example through Qarabagh, directly into the Hazarajat rather than through chak Wardak, a route which is quicker but which involves more travel in Pashtoon areas.

Security for transport from Pakistan will continue to demand good relations with parties and commanders both on the way to and at final destinations. Passage of UN goods is likely to be easier through areas which have recelved some UN assistance than through areas which have not. This lends welght to the 'no leapfrogging' approach advocated by many - whereby the UN should only gradually extend its activities on a strictly geographical basis.

\section{6 Communication}

There was dally radio communication with peshawar andor Islamabad, as well as frequent communication with uNocA Kabul. Reception was usually good although the volume of radio traffic was such that it often took an inordinately long time to convey brief messages. 
The mission had a mandatory call time each day as well as an optional call time. As with all UN missions to Afghanistan, communication between mission members and their respective agencies outside these times was not encouraged. UNILOG's special responsibilities may require separate radio arrangements in the future.

\section{Health}

The health situation in Bamian (and Hazarajat generally) presents a serious challenge to the United Nations, specifically to UNICBF and WHO. Numerous hospitals and clinics were visited and discussions held on general health and health care services with a varlety of health workers and political groups. What follows is a brief summary of observations made, and suggestions for possible future inputs. It 18 by no means exhaustive. Fuil detalls can be found in the separate UNICEF report.

\subsection{Overall assessment}

A preliminary assessment of the health status of the population indicates that the major diseases and related problems are characteristic of those found in the poorest and most neglected areas of Afghanistan. Diarrhoeal diseases, respiratory infections and the vaccine preventable diseases are common among children. During the trip the mission received reports of epidemices of whooping cough, measles, diphtheria and cholera. The most common complaints are of colds, bronchitis, gastritis, worms, non specific muscular/skeletela pain, gottre, scabies and infertility. Mine infuries are common in Bamian city. The mission saw 3 cases in the space of 48 hours.

All these problems are inherent to and exacerbated by the socioeconomic situation. Lack of food security, poor hygiene and health practices, malnutrition, lack of clean water and inadequate sanitation are major factors influencing the health status of the area. 
The war and political Instabllity has had and continues to have an Impact on the health of the people of Bamian and the capacity of the health care services. A number of problems emerged during the visit which were directly attributable to the war and the lack of political unity in the area.

\subsection{Health Services}

Health services are rudimentary and focus heavily on curative care. Many have been disrupted or damaged during the war. Those in existence are closely controlled by the various political parties and lack much needed co-ordination. Those services that are avallable are concentrated mainly in and around the provincial capital and are thus inaccessible to the rural communities in nelghbouring or far off districts. The mission only met 3 fully qualified doctors and 1 t 18 clear that the province is underserved in terms of other levels of health worker.

Agencies working in Bamian have had to work through the parties, which has inevitably shaped the nature of the services provided. There is thus a distinct sense of competition between various facilities and little communication between them. There is no overall coordinating body and no efficlent referral system. Similarly, as limited resources have been shared between four or five centers none of them is adequately equipped. Referral from Bamlan to Peshawar or Kabul is often necessary.

The political difficulties assoclated with health are lilustrated by the case of a young mine victim brought to the Harakat Islami hospital. The hospital was lil-equipped to cope with such an infury. Only basic first ald was possible on the spot. When asked to whom the patient could be referred, the mission was told that no other hospital in the clty was able to deal with the case. After several hours, during which time the little boy was ever closer to death, the closed MSF Belglum/Holland was opened and two German surgeons, who miraculously happened to be in Bamian, 
were able to operate. Only later did the mission discover that the Mustazafin hospital, conveniently situated in the old government hospital bullding at the edge of town, not only had the facllities but would have been very willing to manage the
case.

It seems that the Mustazafin hospltal was not considered because of the political differences between the parties. Such political circulating among the fertile ground for the many of the rumours of malpractice, prices, forelgn doctors. patients, etc.

line Infuries such as the one seen have placed an additional strain on existing services requiring relatively expensive rehabilitation system is essentlal An efficient treatment and disabilities are to be avolded in the fut unnecessary deaths and

\subsection{Outside Medical Support}

The dependence upon Peshawar-based agencles of the few local Bamian is isolated during the winter health workers do not recelve their supplies and and many of the resupply. Some are frequently absent having to and are unable to to report. With a limited number of hing to travel to Peshawar absences cause facilities to closer of personnel anyway, such becomes non existent for many months of the so that health care supply system from peshawar is costly.

It 18 questionable whether any future health infrastructure would be able to sustain the high costs of Peshawar-trained personnel. The possibilities of cooperation between the Kabul and Pakistan profect and for the bexplored, particularly for the EPI supplies. It will also be useful to begin to essential drugs and disparities between Afghanistan to begin to explore reducing the 


\subsection{Immunization}

The Immunization programme in Bamian could be expanded and made avallable through all clinics. The relative stability of the area means that progress could be made, although close monitoring supervision is necessary. Possiblitties of close lialson between UNICEF Kabul and Pakistan need to be explored, both the EPI overall, and the delivery of vaccines and support for a storage point in Bamian.

\subsection{The future}

The political hurdles to providing an efficient health service should not be overlooked. There are, however, signs of hope. The Islamic shura of Bamian has expressed an interest in assuming responsibility for health and supporting an initiative to augment scarce resources. It 18 possible that who/UnICEF could provide the catalyst for a thorough appraisal of the situation and, in confunction with the NGOB working in the province, begin to consider ways of solving local problems. Needless to say, UN inputs in other areas such as emergency food ald, agriculture, and mine awareness could all have a positive effect on the health of Bamian in the long term.

It 1 s essential that a primary health care system be developed. Curative systems should not be developed in isolation. Moreover, the whole health system should be as minimally dependent upon the outside as possible, or rather, as self-sustaining as posible. obvious inputs that will contribute to self-sufficiency include programmes around the control of diarrhoeal diseases, acute respiratory infections, nutrition hygiene and health education.

\subsection{Conclusion}

There 18 considerable scope for improving and coordinating current health services in Bamian and the surrounding areas. It 18 absurd that in a vast area largely devold of health services, 
there are 3 hospltals in one town, none of which 1 s adequate. It must be hoped that the UN can elicit sufficient political will and convergence among local mujahedin groups to rationalise the situation. The establishment of a health committee by the Islamic shura is a first step. The role of this committee could be to rebulid and coordinate the health infrastructure in Bamian town (and, eventually, in the province) and to strengthen curative services.

The field is wide open for UNICEF and who to promote the development of a wider system of primary care with emphasis on CDD, ARI, EPI and supervision of existing health workers. The time is also ripe for programmes in mine awareness, hyglene, and health education, whether through schools or by other means.

\section{Historic sites}

Bamian is the site of many important historic monuments, both Islamic and pre-Islamic. Given their historic and intrinsic significance, remarkably little has been written and researched about them. The mission was only able to make short visits to the sites and, in one case - the 'small Buddha' - was not able to visit the site at all as it was being occupied by a group of mujahedin.

Bamian's most famous landmarks are of course the two Buddhas which, with Band-1-Amir and the shar-e-Gholghola, or the whispering city, were a growing tourist attraction before the war. A large luxury hotel was in the process of being constructed on the hill opposite the Buddhas to cope with the tourist demand before fighting began.

The Kakrak Buddha east of Bamian town is less well known but of great interest, as are the many caves dotted around Bamian Valley - at Qasr-1-Kanishka as well as beside the big Buddhas. Many, If not most of these caves have not been examined in detall. Islamic monuments include the tomb of Khwaja Sabzposh which, like many of the bulldings in the two fortified cities in the valley, zerhak 
and shahr-1-Hoshak, is a tribute to the imaginative use of simple, solid bricks. Zerhak itself $1 \mathrm{~s}$ an unforgettable site, moulded from the dramatic red earth at the southeastern entrance of Bamian valley.

There can be little doubt that, after surviving hundreds and even thousands of years, many of the monuments have been badly damaged In the last decade. Artefacts have been plundered and bullet holes scar the Buddhas. These latter were the scene of fighting during the battle for Bamian town in late; 1988 both sides no doubt saw the advantages of occupying the cliff faces from which the monumental Buddhas and other caves have been excavated: they offered good cover, and their historic value may have been considered additional protection. The cliffs themselves are in danger of collapse in some places, as local farmers continue to remove the calcium-rich soll for their fields; several ancient caves and even the Buddhas themselves originally excavated from the earth around them, are threatened in this way.

The ruins left behind by Genghis Khan on the Shahr-e-Gholghola have been supplemented during the war. The soviets and the GOA used top of the Whispering City as an artillery and lookout post, and the hill is invested with anti-personnel mines.

At a time when so many other vital problems occupy the attention of the international community and of local people trying to make ends meet, prioritising the protection of these monuments may at first seem frivolous. It was interesting to note, however, that this was not the attitude of many local people who had even fust a superficial appreciation of the sites. Members of the Islamic shura and the political parties are fully aware that Bamian is entrusted with a legacy of worldwide importance. If anything, they feel guilty at the abuse the sites have recelved and continue to suffer. They need to be reminded of their responsibility. The UN can help mould this awareness into the realisation of concrete measures to protect and, eventually, restore the monuments. 
Any attempt to protect the sites which does not fully involve local people can only be a short term measure. The responsibility for their protection must remain local. The UN can act as a catalyst, if it is prepared to dedicate sufficient resources to the matter, in bringing about the means. The UN can promote awareness of the significance of the monuments, help ensure that they are not used to house ammunition or host machine gun and anti-aircraft posts, take steps to ensure their physical protection, and train local people to look after them. The establishment by the shura of a committee for historic sites is a good first step. This must now be followed through for any serious attempt to save the monuments to succeed.

The UN has an opportunity to help preserve these monuments for the future. If the resources are avallable, particularly with unesco, it would be almost criminal not to act.

Detalis of Individual historic sites and specific recommendations for action can be found in the Annex Document.

7. Other fields

The mission did not include any agronomist, veterinarian, irrigation engineer, construction engineer or educationalist. It must be hoped that such experts can be sent to central Bamian as soon as possible.

The mission did however gather some basic information: on animal health, agriculture; and mines.

\subsection{Agriculture}

Basic crops in Bamian province are wheat and potatoes. Fruit production has plummeted in the last decade, for example, in the once famous Ajra Valley north of Bamian town near Kamard. It was not possible to survey the extent of irrigated and rainfed cropland. The mission was told that the only produce exported from Bamian 1 s potato and wood, mostly to Kabul. 
No Improved seed 18 locally avallable, although some was sent in 1989 by the swedish Committee which, it was sald, had proved unsultable. Urea from Mazar-1-Sharif occasionally 18 avallable in Bamian bazaar at 1800-2000 Afs per $50 \mathrm{~kg}$ bag. No other fertiliser Is avallable.

Two Government farms (one of 40 feribs, Mullah Ghulam Farm, and one of 20 jeribs at Labidaria) had been under mujahedin control Bince 1981 and are currently rented out by the Islamic shura to private farmers on one year leases. Mullah Ghulam 18 run down but reparable; it used to have a 10 jerib seed multiplication plot on which 20 varieties, mostly from America, were tested; an experimental potato plot (30 varieties, mostly from India) and plots for barley, red beans, turnips, ontons, cucumber, garlic and carrot. It also had a chemical fertiliser and seed store (never completed) and 30 employees. Many of those who administered and worked on the farm are still present, as at Labidaria Farm.

The Bagh-e-Bala tree farm near the alrport, once run by the Land Reform office, has now been completely destroyed. Sald to have been roughly 100 jeribs, the trees have all been cut, mostly for fuel wood in the hard winters, and the area 18 mined. The mission was told that forested areas in private hands have not had such a hard fate.

The mission saw serious flooding of riverine farmland east and north east of Bamian (Shashpul; Ghandak; Do Ab Mikh Zarrin; TalaBarfak; Shumbul; Sheikh Al1). It recelved reports of more serious flooding east of Sheikh All and in many parts of Parwan. While limited flooding 18 a familiar phenomenon, the mission was told the volume and violence of this year's inundation may push many people to quit their land unless relief 18 avallable. An irrigation engineer could be usefully rapidly dispatched to the area to survey the damage and assess possible long term solutions to contain the flooding. 


\subsection{Animal Health}

There 18 no veterinary clinic or veterinarian in Bamian province. This is most disturbing in a region where human and animal health are symbiotic, as are animal health and material wealth.

The animal population has declined dramatically in some areas. Bamian centre, the mission was told, had 30,000 sheep before the war. Now there are none. Fighting, cold winters and diminished access routes have conspired to prevent movement of animals and their owners, resulting in abnormal sale of livestock.

The mission was told of many diseases affecting cows, sheep, horses and donkeys. It was told that rabies are prevalent in several areas.

\subsection{Hines}

Mines pose a major danger to the population around Bamian Town. The mission saw three children, shepherd boys, who had been infured by mines in the first three days spent in Bamian centre.

The location of mines was well documented by an Afghan a consultant to UNOCA in late 1989. (See the Moussavi Report of visit to Bamian). He recommended that immediate action be taken to mark and destroy the mines.

A team of mine surveyors from Afghan Technical Consultants arrived in Bamian on June 18 th 1990 and made contact with the Islamic shura and its newly established committee. A survey of the area south of the airstrip has already been undertaken and several live mines uncovered and exploded.

On 1ts return fourney, the mission saw a large quantity of new anti-tank mines in Daymirdad, Wardak being transported northwards. It is disheartening that mines continue to be laid in large quantities. 


\subsection{Mine Awareness}

Knowledge of the dangers posed by mines among the local population, especially children, is lamentable. One infured child seen had lost use of his hands after losing a game of dare devil' with his friends which had involved playing with a live mine.

Basic mine awareness training for all sections of the population in Bamian centre 18 badly needed. The only other area visited where mines pose a major hazard to the population was Tala-Barfak in Baghlan. However, moves to de-mine this area might meet resistance as some mujahedin consider it to be a 'front line' against the Government. Again, mine awareness training would be an obvious interim step.

\section{Some conclusions}

The mission leaves recommendations for action to be decided by readers of this report and interested UN agencies. A number of salient points, in no particular order, may be useful in deciding the next steps to be taken

a) The UN has to decide whether it is prepared to give priority to an area that by Afghan standards is least developed and whose people are possibly the poorest and most vulnerable in the country.

Central Afghanistan is neither a major 'refugee return' area nor as directly affected by fighting as some other areas. That 1 ts refugees have gone to Iran rather than Pakistan may have made the UN less sensitive to its problems that it might otherwise be. Yet it includes the poorest part of Afghanistan, the Hazarajat, and the lives and meagre economy of its people have been indirectly undermined by 10 years of conflict. 
b) The UN's varlous offices in. Iran, Pakistan and Afghanistan need to decide to what extent Bamian can serve as a mutually useful operational centre. The size decided.

As this report detalls, Bamian offers many strategic advantages as a base of operations, not just for the west but also to the east, around Kabul.

It is particularly important that the shura's initiative in setting up eight civilian committees be pursued. The UN should also decide how to respond to the offer of a permanent office site. (The temporary office 15 already being used by the de-miners.) If 1 t is accepted, the site needs to be reconstructed. It would be the first building to be repalred in the old hilltop 'wilayat' or administrative quarters.

For their part, participants of this mission hope that the UN will see fit to begin serlous work from Bamian. If, for example, a salam Moblle Unit is to be established, it should only become operational once the appropriate skills are assembled to take part. These must Include, as a minimum, an agronomist, a veterinarian, an Irrigation engineer, a construction engineer, an educationalist and a public health speclalist.

A positive attitude towards the people of central Afghanistan, as well as willingness to remain in the area for considerable stretches of time, are required. The UN must also be willing to maintain staff in the area during the often bitter winter months.

c) If Bamian is to become a UN operational centre, logistics arrangements need to be determined.

While the use of GOA held cities as points of distribution for assistance would seem to pose no political problem to the mujahedin in Bamian (though

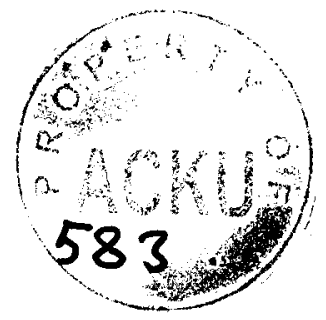


varlous practical problems need to be solved), it makes

sense, whenever possible, for UN staff, particularly Afghan staff, to come from other locations. If International staff members are to be sent to Bamian from Kabul, it would be best if they had first visited the area from elsewhere. Deep appreclation was repeatedly expressed to the mission for traveling the arduous route from Peshawar; this store of good will should not be squandered.

The use of the alrstrip at Bamian should now be seriously considered. There are no local objections to its use, and it is in usable condition.

d) The UN needs to decide whether 1t can invest sufficient time and resources to pursue the objective of training and developing a local civilian administration which can then act as 1 ts partner.

The prime concern of any future UN presence should be to develop the local civilian administrative capability to manage the area's problems. The establishment of 8 committees in Bamian town is a first step which should now be followed through.

The very strong local sense, forged by necessity, of self-sufficlency should not be undermined. The providers of food assistance have a particular responsibility in this regard. Training of local people must have high priority, whether in the fields of health, education, administration, protection of historic monuments, de-mining, project proposal writing etc. Bamian is a long way from Peshawar and should not become dependent upon $1 \mathrm{t}$.

The development, with uN help, of a civilian administration in Bamian could have a profound impact. 
e) If the 'UN' is to encourage the continued and even expanded presence of NGOs tt should be only on the basts of their willingness to promote local selfsuffictency.

The UN can help NGOs resist political pressures which have resulted in irrational distribution of atd resources, e.g. In the health field.

An initial assessment of the security situation and the attitude of local authorities would indicate that there is little reason as to why NGos, like the UN, should not have their own local offices rather than try and run programmes by remote control. clearly, NGos themselves must decide whether they have sufficient resources to do this.

Several NGos have considerable experience in the area; their advice has already proved very helpful and should continue to be sought by the UN. 
- International officers:

Mchael Keating

Ke1 Kimpara

Caroline sergeant

Gerard viguie
UNOCA (Team Leader)

Field officer, Peshawar

UNILOG, Fleet Manager, Peshawar

UNICEF, EPI Consultant, Peshawar

WFP, Head of Afghan Relief and Rehabilitation office, Islamabad

\section{* Afghan National Officers:}

Dr. Abdul Wasay Nafimi UNBSCo, short Term Consultant (Seconded from Swedish Committee)

Mohammed Yusuf Sabah WFP, Field officer Quetta

other staff:

Mohammed Wall

Abdul Jabbar

Mohammed Wal1

Merajuddin

Azad Mir
Translator for UNICEF

Translator for UNOCA

UNOCA Driver

WFP Driver

UNILOG Driver 
21

1,

Bamian Bound:

Salam Mission Report

ANNEX DOCUMENT

llay 29 - June 19,1990 


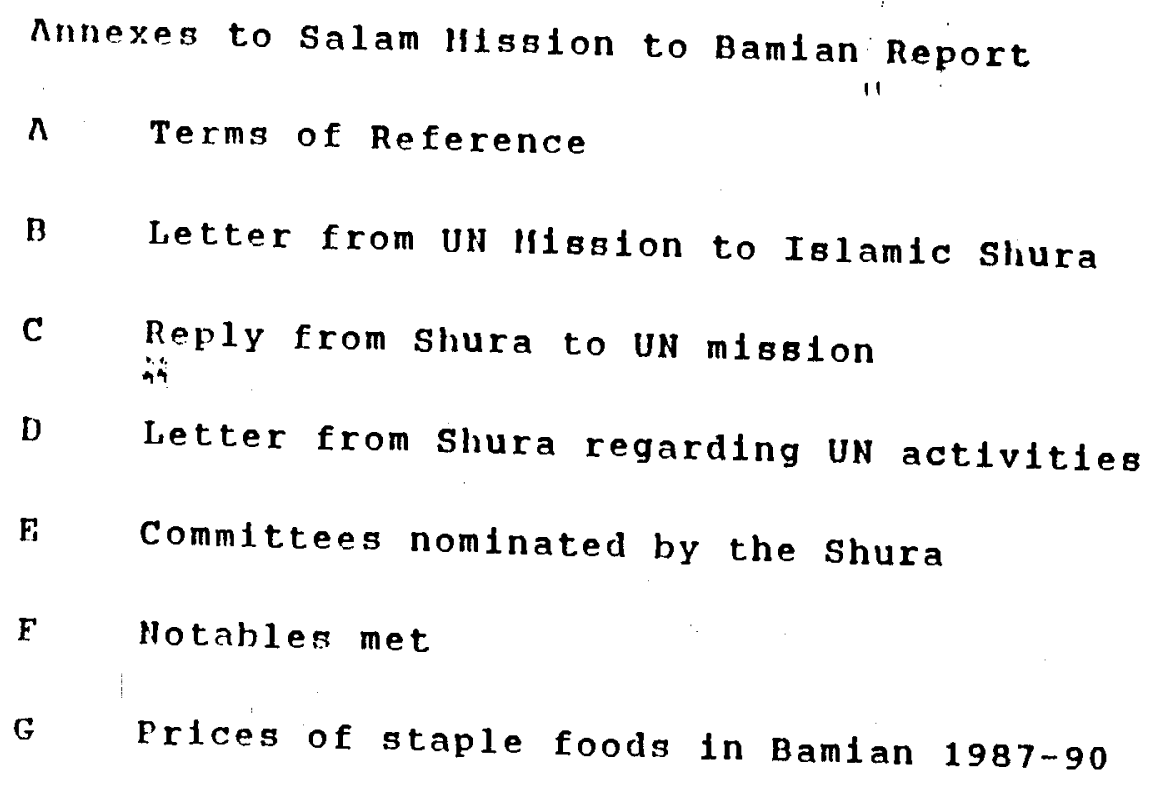




\section{4}

nHHFX $\Lambda:$ Termb of Reference

\section{UHICFF}

1. To assess the general health and education situation, requirements, and suggest possible inputs

2. To review existing health and education facilities

3. To assess UNICEF supported projects (e.g. immunisation)

4. To assess the possibilities of educational support
outside the current NGo framework UNILOG

1. To survey road conditions, storage facilities, avallability of fuel, Bpare parts, mechanics, workshops
and warehouses

2. To identify a counterpart for UNILOG from among local transporters or NGOs to assist in the establishment of a local UNILOG base

3. To identify potential checkpoints and service points WEP 1. To assess current agricultural conditions and the
harvest and to estimate food needs

2. To collect information on availability and cost of main staple foods 3. To identify the potential of food-for-work and the need
for vulnerable group feeding

1. To identify potential implementing partners 5. To monitor the results of the recent delivery of 500
tons wheat from Mazar-1-sharif 
Unocn

1. To assess the overall situation

2. To aroess the sultablitty and feasibllity of establishing a UN presence In Bamian

ऊi: To assess the problem of mines

4. To facilitate the work of UNIDATA in the area

UNESCO

1. To assess present condition of cultural monuments and sites

2. To encourage steps for the protection of these sites by local authorities

3. To assess priority protection measures (surveys, equipment etc.) 
ANHFX D: Letter from UN Misgion to IBlamic Shura, Bamian

To: The Islamic Shura of Bamian

Date: June 7 th, 1990

Jанza 17,1369

From: The United Nations lission

to Bamian
\end{abstract}

Respected Sirs

Thank you for the warm welcome which you have extended to us and for your willingness to cooperate with us in starting work in this area. nt your request, we now give you the objectives of our mission so that you may consider them and that we may benefit

As you know, we arrived here on th June and will stay until 14 th June. The mission includes representatives of United Nations
offices responsible for:

1. Providing food to encourage reconstruction activities 2. Improving the health situation, especially for women and
children

3. Establishing logistics routes and means of transporting United Nations assistance to the areas where it is needed

4. Providing education and the presentation of cultural

5. De-mining, mine awareness teaching and help for the disabled

We hope to bring representatives of other UN offices to Bamian bron, espectally for agriculture and reconstruction (roads,
bridgen

The objectives of this first un misBion to Bamian are:

1. To find out if the presence of the United Nations 18 welcome among all groups 


\section{a}

2. To see if it is safe for the United Nations to begin its work.

3. To establish an office on ground which will be considered neutral and, once provided to the United Nations, which belongs to no party. i

4. Host importantly, to establish a working relationship with local authorities whereby the advice and views of all groups and parties is taken into consideration and whereby the plans, activities and achievements of the uN are known to everyone.

5. To establish, in discussion with the local authorities, the guidelines for the United Nations in undertaking its reconstruction activities. For the United Nations 18 not allowed to work with military groups or with local reconstruction committees which are willing to help only one party. Ideally, the UN would like to work with technical committees which are acceptable to all groups and parties. We recommend that to begin with, four technical committees are established: in health, education, reconstruction and agriculture. We will also need to work with committees responsible for the historic sites of Bamian which are treasured by people throughout the world, and a committee for demining. For example, a small team will come to Bamian from Peshawar in ten days to survey the mines and make plans for their removal and destruction. To whom should this team report?

The guidelines for the United Nations should therefore also Include the policy for employment of local people, both to look after our office and to undertake projects.

For reducing economic and logistics problems, the United Nations needs to be able, to bring assistance from various places along various routes. We will seek your help in providing security of routes. 
The United Nations office, once estab vant to work in other nearby Bamian. other nearby provinces that are accessible from Your guidance and advice appreciated. on the above points will be deeply With highest consideration

Michael Keating

UNITED NATIONS OFFICE OF THE CO-ORDINATOR OF ASSISTANCE TO 


\title{
34
}

AnHex $C$ : Letter from shura to UN M18Bion

To: The respected UN mission Date: June 5,1990

\author{
i \\ From: The Islamic Shura of Bamian
}

The Ul mission is already welcome in Bamian and we thank you for your co-operation in reconstruction of Bamian.

lleanwile we have studied the letters from you regarding UN objectives, and all the subjects mentioned therein are confirmed. The Islamic Shura of Bamian, beside cooperating with the UN mission, will appreciate further consultations upon the implementation of projects and the responsibilities of both sides. We stress upon neutrality and full consultation.

Signed

- Ak11, Secretary of shura

- llastu, Rep of llustazafin

- Kasiml, Rep of Harakat Islami

- Zak1, Sazman Nasr

- Wasek, Rep of Pasdaran

- Khwaja lloh'd, Mahaz-1-M1111

- Baratal1, llarakat Ingelab

- Rahmanuliah, Rep of Jamiat

- Ho'alem llusakhel, Hezb1-Islam1 
NWWFX D: Letter from Shura to H18s'ion regarding UN activities

\section{Islamic Shura of Bamian}

$23,3,4369$ Emergency meeting of authorized members of Islamic shura concerning following items.

1- These places have been proposed for the temporary office of for UN teams: either private houses, rented by the UN, or the caravanseral at Tupchi which needs to be rebuilt, or the High school, which should be repaired for students.

2- The Islamic Shura agrees to organise different committees in different fields, which should have one representative from each party.

3- According to the shura's decision, a man from Hezb-1-Islami has been appointed [by lottery] to run the un office.

4- The alrstrip has been selected/appointed on a parking for uN logistics cars and 1 ts destroyed bullding is next to the parking.

5- UN teams can select any individual to work with in each fjeld on the list of names 1ntroduced by the shura, and the Shura will not interfere in future.

6- The telecommunication center, which is markaz Bamian [Wilayat] has been appointed for the permanent office for UN. The UN needs to rebulld the place for use. 
Annex E: Elght Committees nominated by the shura

List of members of different Committees

Health Commision

\begin{tabular}{|c|c|c|c|c|c|}
\hline S. Ho. & Name & Resident & Party & Education & $\begin{array}{c}\text { Previous } \\
\text { Job }\end{array}$ \\
\hline 01 & Dr. Said Raza & Iraq & Harakat-1-Is lam 1 & M.D. & \\
\hline 02 & Dr. Gul Rahman & Somara & Jam 1 at-1-I s 1 am 1 & 14 grade & Doctor \\
\hline 03 & $\Lambda m i n$ Jan & Gharibabad & NIFA & 12 Grade & C1vil gervan1 \\
\hline 04 & llukhtar & Shashpul & Hustazafin & Ph.D. & Doctor \\
\hline 05 & Abdul Zahoor & Gharibabad & Hezb-1-Is lam 1 & 12 c 1 ass & Drug sale \\
\hline 06 & $\operatorname{sh} 1 \mathrm{rin}$ & & Pasdaran & H1gh school & \\
\hline 07 & s. Abdul Wahld & Katury & Nasr & & \\
\hline 08 & llerajudden & Dahody & Harakat 1 Inqelab & Teacher Tr. & \\
\hline
\end{tabular}

List of Members of Different Committees

Teaching and Training Commission

\begin{tabular}{|c|c|c|c|c|c|}
\hline S. No. & Name & Resident & Party & Education & $\begin{array}{c}\text { Previous } \\
\text { Job }\end{array}$ \\
\hline 01 & H. Zaher & Saldabad & Harakat-1-Is lam 1 & Sclence & Teacher \\
\hline 02 & Ghulam Qader & Hulayan & $\operatorname{Jam} 1 \mathrm{at}-1-\operatorname{Is} \operatorname{lam} 1$ & 14 Clas & $n$ \\
\hline 03 & zulmai & Gharibabad & NIFA & $12 \mathrm{Clas8}$ & $n$ \\
\hline 04 & Haj 1 sefut & Shashpul & llustazafin & Diploma & " \\
\hline 05 & Hehrabuddin & Ilulayan & Hezb-1-I s lam 1 & 14 Clas & " \\
\hline 06 & Abbas Jaffery & Pakan 1 & Pasdaran & 14 Class & $n$ \\
\hline 07 & llajt serajudin & Dahody & Harakat 1 Inqelab & $14 \mathrm{Clas8}$ & $n$ \\
\hline $0 B$ & $\operatorname{Imam} n 11$ & Turman & Nasr & Diploma & $n$ \\
\hline
\end{tabular}




\section{List of nembers of different Connitteen \\ Agriculture Comisaton}

\begin{tabular}{|c|c|c|c|c|c|}
\hline S. Ho. & Name & Resident & party & Education & $\begin{array}{c}\text { Previous } \\
\text { Job }\end{array}$ \\
\hline 01 & 11. Taher & Gurman & Harakat-1-I g lam 1 & Graduate & \\
\hline 02 & Ismatullah & Gharibabad & Jam 1 at-1-I B lam 1 & $12 \mathrm{Ca} 188$ & Technical Man \\
\hline 03 & nbdul Fatah & Ghar 1 babad & NIF $\Lambda$ & $6 \mathrm{Class}$ & \\
\hline 04 & $\begin{array}{l}\text { Hamur Noor } \\
\text { Nhmed }\end{array}$ & Dahody & Harakat1 Inq1lab & & Technical Man \\
\hline 05 & Besmillah & Tajik & Hezb-1-Is lam 1 & Graduate & \\
\hline 06 & $\begin{array}{l}\text { llussain } \\
\text { llamdard bakhsh }\end{array}$ & Ghazn 1 & Nas $\mathrm{r}$ & $\begin{array}{l}\text { 2nd Grade } \\
\text { faculty }\end{array}$ & \\
\hline 07 & Didar $\wedge 11$ Joya & Fulady & Pasdaran. & & \\
\hline 08 & Sula 1 man & Shashpul & Mustazafin & Diploma & \\
\hline
\end{tabular}

List of Members of Different Committees

Engineering \& Construction Commission

\begin{tabular}{|c|c|c|c|c|c|}
\hline S.Ho. & Name & Restdent & Party & Education & $\begin{array}{c}\text { Previous } \\
\text { Job }\end{array}$ \\
\hline 01 & $J$ an 11 & Saldabad & Harakat-1-Is lam 1 & Graduate & Teacher \\
\hline 02 & 11. $\Lambda \mathrm{n} 1 \mathrm{f}$ & Taj1k & $\operatorname{Jam} 1$ at $-1-I \sin 1$ & Graduate & Englneer \\
\hline 03 & 1I. Kazim & Ghar 1babad & NIFA & 6 Class & Mason \\
\hline 04 & Eng. Imamuddin & $\mathrm{Taj} \mathbf{1 k}$ & Harakat 1 Inqelab & & \\
\hline 05 & 11. Hussain & Eulady & Nasr & 12 Class & \\
\hline 06 & Muslim & Fulady & Pasdaran & Kabul Tech. & \\
\hline 07 & Eng. Qad1r & Sar $\Lambda \mathrm{B} \perp a b$ & Mustazafin & Ma, Elect. & \\
\hline 08 & Abdullah & Gharibabad & Hezb-1-Is Iam 1 & Eng. Facul. & Hason \\
\hline
\end{tabular}




\section{List of members of different comittees \\ De-mining o mine clearence comasion}

\begin{tabular}{|c|c|c|c|c|c|}
\hline S.Ho. & Name & Resident & Party & Education & $\begin{array}{c}\text { Previous } \\
\text { Job }\end{array}$ \\
\hline 01 & nbdul Ham $1 \mathrm{~d}$ & Said Abad & Harakat-1-Is 1 am 1 & & \\
\hline 02 & Tala 11 & Jui shahr & $\operatorname{Jam} 1$ at-1-Is 1 am 1 & 12 C 1 ass & ' \\
\hline 03 & nbdul ahoor & Ghartbabad & NIEn & 12 C 1 ass & \\
\hline 04 & Azim llussaint & Fulad 1 & Pasdaran & $9 \mathrm{Class}$ & \\
\hline 05 & Said llohammed & Gurman & Nas r & 12 Class & \\
\hline 06 & Tartq & ShashPu 1 & Hustazafin & 12 C 1 ass & \\
\hline 07 & Abclul Nhmed & Dahody & Harakat1 Inqelab & 12 Clas8 & \\
\hline 08 & Abdul sattar & Ghar 1babad & Hezb-1-Is 1 am 1 & $12 \mathrm{Class}$ & \\
\hline
\end{tabular}

List of llembers of Different Committees

Food for Work Commission

\begin{tabular}{|c|c|c|c|c|c|}
\hline S.No. & Name & Resident & Party & Education & $\begin{array}{c}\text { Previous } \\
\text { Job }\end{array}$ \\
\hline 01 & H1rza Hussain & Sar $\Lambda s 1 a b$ & Harakat-1-Is $\operatorname{lam} 1$ & 14 Class & \\
\hline 02 & Khatr Itohammed & Lala KhIl & Jam 1 at $-1-I s \operatorname{lam} 1$ & 14 C 1 ass & Teacher \\
\hline 03 & nbdul Wak11 & Ghar 1babad & NIF & 12 Class & \\
\hline 04 & Hoh'd Jabery & Fulady & Pasdaran & $12 \mathrm{C} 1 \mathrm{ass}$ & \\
\hline 05 & Hohammed Taq1 & Gurman & Nasr & 12 C 1 ass & \\
\hline 06 & $n z 1 z u l l a h$ & $\begin{array}{l}\text { Dast } \\
\text { Isa Khan }\end{array}$ & llustazafin & Graduate & \\
\hline 07 & Abdul llukhtar & T1but 1 & Hezb-1-Is lam 1 & 12. Class & \\
\hline 08 & 11. llasoom & Dahody & Harakat 1 Inqelab & $12 \mathrm{C} 1 \mathrm{as} 8$ & \\
\hline
\end{tabular}




\section{List of members of different comittees \\ Transportation Comaission}

\begin{tabular}{|c|c|c|c|c|c|}
\hline S. Ho. & Name & Resident & Party & Education & $\begin{array}{l}\text { Previous } \\
\text { Job }\end{array}$ \\
\hline 01 & Ifohammed Dauad & Eraq & Harakat-1-Is lam 1 & 12 C 1 ав 8 & \\
\hline 02 & $n z 1 z$.hmed & Ghar 1babad & Jam 1 at-1-Is 1 am 1 & $12 \mathrm{Clas8}$ & Accountant \\
\hline 03 & llubin nhmed & Gharibabad & NIFA & $12 \mathrm{Clas} 8$ & Agriculturist \\
\hline 04 & $\begin{array}{r}\text { Ghulam } \wedge 11 \\
\text { Toofan }\end{array}$ & Fuladi & Pasdaran & $12 \mathrm{Class}$ & \\
\hline 05 & S. Nimatullah & Fulad 1 & Nasr & 12 Class & \\
\hline 06 & Haft $\Lambda$ man & ShashPul & Mustazafin & Graduate & \\
\hline 07 & $111 \mathrm{rza} n z 1 z$ & Tibut 1 & Hezb-1-Is lam 1 & Graduate & \\
\hline 08 & Hussa1n Jan & Dahody & llarakat 1 Inqelab & Graduate & \\
\hline
\end{tabular}

List of llembers of Different Committees

Archealogy llonument Commtsion

\begin{tabular}{|c|c|c|c|c|c|}
\hline S. No. & Name & Resident & Party & Education & $\begin{array}{c}\text { Previous } \\
\text { Job }\end{array}$ \\
\hline 01 & Ghulam llussain & Saldabad & Harakat-1-Is $\operatorname{lam} 1$ & Ph. D. & \\
\hline 02 & Abdul Nabl & Tajtk & Jam 1 at $-1-I s \operatorname{lam} 1$ & $12 \mathrm{Class}$ & \\
\hline 0.3 & Ghulam Jan & S1a La1k & NIF & $6 \mathrm{Class}$ & \\
\hline 04 & Hazir llussatn & Fulady & Pasdaran & High School & \\
\hline 05 & Satd Khan nga & Khushkak & Nasr & $12 \mathrm{Class}$ & \\
\hline 06 & $\operatorname{Vas} 1 q 1$ & $\begin{array}{l}\text { Shashpul } \\
\text { Isa Khan }\end{array}$ & Mustazafin & $\begin{array}{l}\text { Fh. D. } \\
\text { (Biology) }\end{array}$ & \\
\hline 07 & IIajl Abdullah & Dahody & Harakat1 Inqelab & $12 \mathrm{Clas} 8$ & \\
\hline 08 & Fematuld ah & Ghar 1 babad & He $z b-1-I s 1 a m 1$ & & \\
\hline
\end{tabular}


MHifx $F$ : lotables met during the mission is

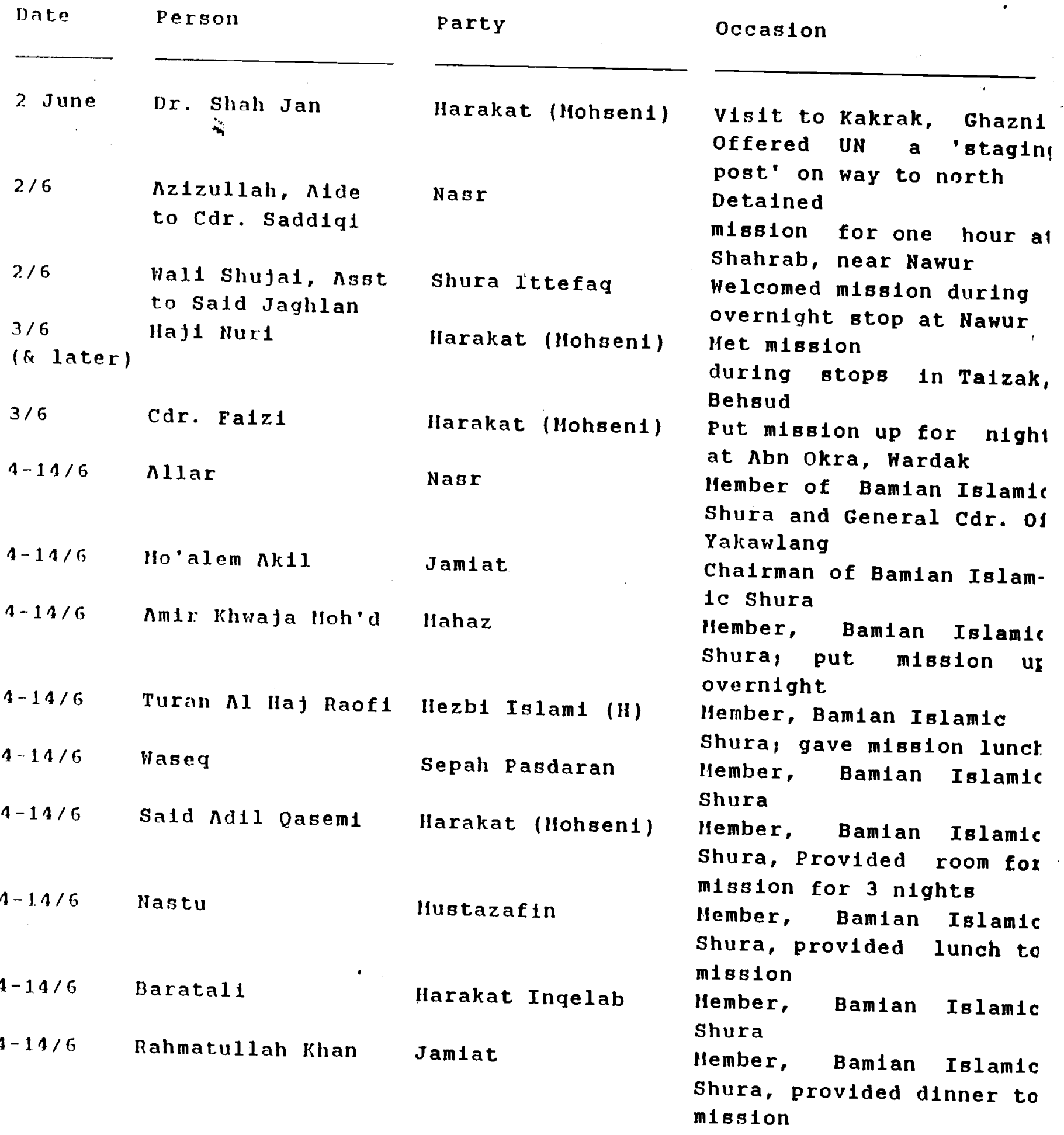




\begin{tabular}{|c|c|c|c|}
\hline $5 / 6$ & zak 1 & $\begin{array}{l}\text { Harakat (Hohsent) } \\
\text { (Bamian) }\end{array}$ & $\begin{array}{l}\text { Member, Central } \\
\text { Committee, Hezbi Wa'adat } \\
\text { Met with mission }\end{array}$ \\
\hline $5 / 6$ & Nat1q1 & Nasr (Uruzgan) & $\begin{array}{l}\text { Member, Central committel } \\
\text { Hezbi Wa'adat }\end{array}$ \\
\hline $5 / 6$ & $\operatorname{Urfan} 1$ & Nasr (Bamian) & $\begin{array}{l}\text { Member, Central Committel } \\
\text { Hezb1 Wa'adat }\end{array}$ \\
\hline $5 / 6$ & llustafa Qasimi & Pasdaran Jehad & $\begin{array}{l}\text { Member, Central Committe } \\
\text { Hezbi Wa'adat }\end{array}$ \\
\hline $5 / 6$ & $\operatorname{Razm} m_{i} J u$ & $\begin{array}{l}\text { Harakat (Hohsen } 1) \\
\text { (Parwan) }\end{array}$ & $\begin{array}{l}\text { Member, Central Committe } \\
\text { Hezbi Wa'adat }\end{array}$ \\
\hline $5 / 6$ & Husseinyar & $\begin{array}{l}\text { Jabha-e-Mottahed } \\
\text { (Balkh) }\end{array}$ & $\begin{array}{l}\text { Hember, Central Committer } \\
\text { Hezbi Wa'adat }\end{array}$ \\
\hline $5 / 6$ & Ehsan 1 & $\begin{array}{l}\text { Shura-e-Ittefaq } \\
\text { (Bamtan) }\end{array}$ & $\begin{array}{l}\text { Member, Central Committer } \\
\text { Hezbl Wa'adat }\end{array}$ \\
\hline $5 / 6$ & Sadd1q1 & Nasr (Parwan) & $\begin{array}{l}\text { Member, Central Committer } \\
\text { Hezbl Wa'adat }\end{array}$ \\
\hline $5 / 6$ & Qasem Naliq1 & Pasdaran Jehad & $\begin{array}{l}\text { Member, Central Committer } \\
\text { Hezbi Wa'adat }\end{array}$ \\
\hline $6 / 6$ & Qaz1 Lutfullah & $\mathrm{Jam} 1 \mathrm{at}$ & $\begin{array}{l}\text { Gen. Cdr. Shashpul, Bami. } \\
\text { an; hosted mission }\end{array}$ \\
\hline $7 / 6$ & Eng. Hashem 1 & Mustazafin & $\begin{array}{l}\text { Head of 'Elders' Shura } \\
\text { lunch }\end{array}$ \\
\hline 年 & Eing. Hashemi & Mustazafin & $\begin{array}{l}\text { Bamian Head o: } \\
\text { llustazafin. Met at hil } \\
\text { base and in Tala Barfak }\end{array}$ \\
\hline $8 / 6$ & Hohammed 1 & Nas $\mathrm{r}$ & $\begin{array}{l}\text { Chairman, Yakawlang Is. } \\
\text { lamic Council. }\end{array}$ \\
\hline $11 / 6$ & Haj1 nbdul & $\begin{array}{l}\text { Harakat Inqelab } \\
\text { (Hahaz?) }\end{array}$ & $\begin{array}{l}\text { Put mission up overnight } \\
\text { at Hangaran, Shashpul }\end{array}$ \\
\hline $13 / 6$ & Bas lloh'd Khan & $\begin{array}{l}\text { Ilahaz-1-11111 } \\
\text { (Tala Barfak, } \\
\text { Baghlan) }\end{array}$ & $\begin{array}{l}\text { Put mission up overnight. } \\
\text { helped provide Bamian } \\
\text { office }\end{array}$ \\
\hline $15 / 6$ & Qazd Nad1m & $\begin{array}{l}\text { Hezbi (H) } \\
\text { Daymirdad, Wardak }\end{array}$ & $\begin{array}{l}\text { Held mission up for } 2 \\
\text { hours at Daymirdad, beal } \\
\text { up Harakat Commanders }\end{array}$ \\
\hline $15 / 6$ & Eng. $n_{s 1 f}$ & $\begin{array}{l}\text { llezb1 (H) } \\
\text { Chak Wardak }\end{array}$ & Gave tea to Mission, Chal \\
\hline
\end{tabular}


AHNFi G: Prices of ataple foods

The price in $\Lambda$ fghanis of main staple foods, according to locall! gathered information, has increased as follows in Bamian province il the last four years:

Commodities

$7 \mathrm{~kg}$. Wheat

$\dot{x}$

7 kg. Rice

One Box Veg.

$011(17 \mathrm{~kg})$

$7 \mathrm{~kg}$. Fotatoes

$7 \mathrm{~kg}$. Onton

one llotel meal
87

200

480

950

500

900

1000

80

210

180

90 Remarks

840 from 950 to 120011 Yakawlang ; about 1000 in shambul

2500

8000

$$
\begin{aligned}
& 280 \text { Local surplus } \\
& \text { exported }
\end{aligned}
$$

2500

$50 \quad 80$

180 
AHHFX II: WFP projects monttored during the mission

1. 500 IIT wheat and 50 UT sugar were dispatched early 1990 from llazar-1-sharif, through the "area controlled by sayed llansour, to Bamian.

The 500 IT were distributed as follows:

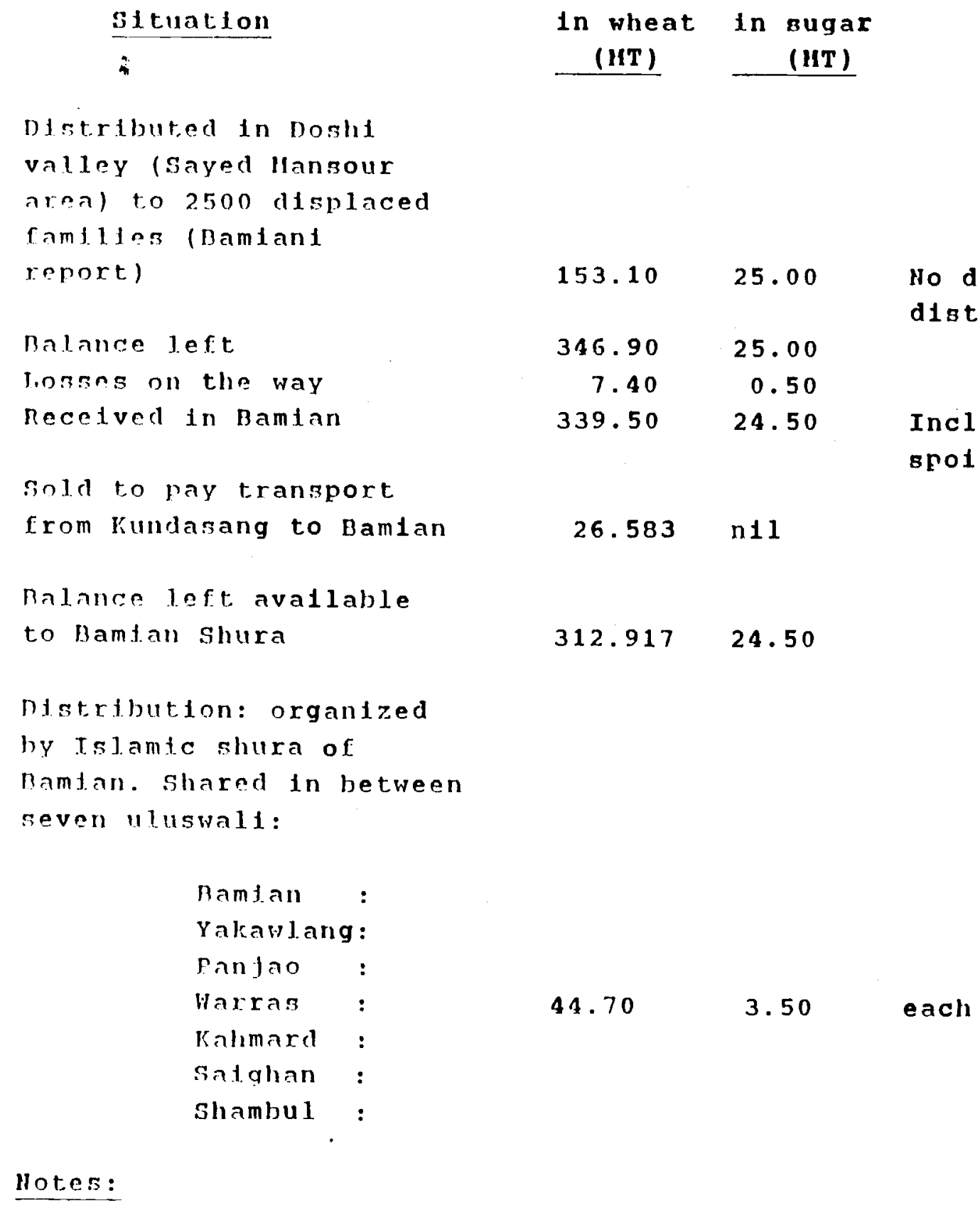

a) In Bamian 1tself 10 llT of spolled wheat was sold for cattle as well as 18 IIT of good wheat to meet local handling costs and expenses incurred by the shura. At the same time $16.5 \mathrm{MT}$ of whent and 3.5 liT of sugar was shared between the political parties within this shura. 
b) Everywhere else, the sugar was sold to pay the transport costs from Bamian. The wheat was distributed malniyto vulnerable groups. The mission Interviewed several beneficlaries at random in Yakawlang for detalled checking: 1256 beneficiarles, mostly disabled, orphans andwidows, got 44.70 IIT of wheat. In other districts, information was provided by the shuras.

c) Given that the shura was left without guidelines and that nabody was present in Bamian to recelve the food or monitor its distribution, the result is not so bad. Prior arrival of the food helped ensure a warm welcome for the mision. However, to avold further confusion and misunderstanding, an official letter was sent to the Islamic shura of Bamian (Annex L) which subsequently appopinted an elght man committee, from which ARRO can chose a counterpart, to deal with future food ald projects.

2. 400 IIT wheat dispatched from Peshawar to Behsud/Tizak as part of the $1,200 \mathrm{MT}$ project with AVICEN.

This wheat was recelved and monitored by two local staff, including an agronomist, of AVICEN In Behsud/Tizak district. Notwithstanding an avariclous local commander, 1645 families recelved the food. A random survey revealed no misuse of the wheat, although AVICEN can st1ll improve targetting of the beneficlaries. Beneficlartes are very poor, but many could have received assistance through food-for-work projects.

An example lllustrates the poverty of some people: one man met had both his own family (one wife, two elderly dependents, and 8 children) and that of his brother, currently jalled in Kabul (the brother's wife and her 9 children) to look after. The man in question has 1.5 Jeribs of land and 22 people to care for. of six other families interviewed at random, four were in a comparable situation for reasons directly related to the war.

Unfortunately. It is too late to rhange this Avicen profect for the wheat st1ll to be dellvered, flrstly because so far only one part of the district has recelved assistance and there would be considerable unrest if the other parts recelve nothing, and secondly because AVICEN 18 not yet In position to organize food-for-work projects. Moreover the local commander cannot be trusted. 
The mission w111 however request that $38 \mathrm{MT}$ of the wheat still to come be given to Imam Mahdl school, $25 \mathrm{Mr}$ tor 200 chlidren, Including $60 \mathrm{glrls}$, over one year (400 grams per day) and $13 \mathrm{MT}$ for the staff (7 kg. per man/day).

3. MSF project (AFG 49) - $898^{\prime}$ M' for vulnerable groups In Yakawlang.

This profect was not implemented as planned, Initlally because the road was st1ll closed, and subsequently because isf The profect should therefore be cancelled and replaced as detalled in Annex $J$ below.

4. Hercy Fund profect - $200 \mathrm{MT}$ for Bamian

In 1989, 200 MT was d1spatched from Peshawar. Th1s wheat never reached 1 ts destination, Initially because the Hajl Gak Pass was closed. After investigations made in Bamian, Chak Wardak and shelkhabad, the following conclusions can be drawn:

a) $40 \mathrm{MT}$ was off-loaded by Hezb1 Islam1 (Hekmatyar) In Chak Wardak and locally distributed.

b) The remalning $160 \mathrm{MT}$ was sold by a commander in sheikhabad, Wardak. This commander, with whom Mercy Fund worked, 18 from Salghan in northern Bamian, belonglng to Hezbl Islaml (Khales). The Islamic shura of Bamian heard about this, but was not Involved in the sale. Unfortunatelythe wision was unable to go to Salghan to meet the commander because of uncrossable rivers. Further Investigations w111 be pursued with Mercy Fund, if this information 18 confirmed, the commander should be black listed. 
nHHEX J: Emergency and relief assistance projects

1. Yakawlang district

llembers of the mission travelled by horseback to some of the valleys west of Yakawlang bazaar and, at the shura of Yakawlang's away. There, by a village age of Sare Tarnok, about $25 \mathrm{~km}$ from in the earth's plates had perched at 2,850 , it found that a shift been crumpled, topsoli elther a a local disaster: fields had down cracks in the ground.

Local people said they had lost 300 feribs of cultivable land, and that $1 / 4$ of the remaining 400 jeribs had been damaged, along
with many houses and, most importantly, their canals.

It is almost certain that if not helped the villagers will have become internally displaced. Young men may go to Iran. To prevent
this the UN could send wheat quickly; but only when UN there to recelve it and designickly; but only when UN staff are this could be done at the end of July.

The UN should be prepared to assist about 1600, beneficiares mission, or by local UNOCA-recrutien be conducted by the next needs. If necessary, food-for-work projects should assess further although the local people need little fust need food while they $f 1 x$ their lands. for 3 months could be provided to begin with, before an accurate
survey and plan of distribution of wheat.

It 1 s obvious that these people need wheat more than advice. In Yakawlang, there is a warehouse (800 MT capacity) built by the Germans before the war and still in condition to receive wheat.
(It is empty now, except one captured tank)

2. Slielkh nli in Parwan

Several thousand people of this district have been affected by floods this spring. The mission was told that large number of very poor harvest. This clearly their cultivated land and expect a survey of the 23 villages affected to be checked. At least one possible. Again, immediate affected should be done as soon as is in Bamtan. 
pruture Bamian sllu could get assistance from Doctor Jeannot presently in Tanorit village for 'survey and monitoring. Local staff should be recruited for the operation.

3. Food for work and school feeding poselbilities:

a) Bamian

In the event that a sHU is approved, there are many potential tasks for the UN and WFP:

- Several state farms to be rehabilitated (former staff are still around; eg Mr. Bismillah/Hezbi, Bamian markaz)

- IIr. Najini, UNesco consultant, can develop several proposals to protect and clean the historic sites. These proposals should be carefully drawn up with other profects which will benefit the local population immediately.

- The alrport needs to be rehabilitated for use, including its bulldings (UNILOG is to send two tents there)

- The Uluswali bullding could to be rebullt as well as many of the old public buildings in the wilayat. Both the permanent and the interim UN office sites needs to be rebullt.

- A number of bridges need to be rebullt in the area.

- llany roads need repair, sometimes minor work. linn:m narl c:leanln!

- 'l'ree plantation projects could be undertaken.

500 IIT of wheat and two Rubb-llall tents should be pre-positioned for use by the sMU.

b) Yakawlang

500 IIT could be sent for local projects and for use by the sHu. In addition to the food-for-work, school feeding could begin here. ( In Bamian, Shashpul and Kalu there $1 \mathrm{s,}$, an education committee. They have twelve schools covering ten villages each. Schools are closed in December. in experiment could be undertaken: the objective being not nutrition, but increase in school attendance.. A small project could be undertaken: 1240 children $x 400$ grams $x 3$ months of school +2 months ration to bring home + one ser per day for staff ( 37 over a 3 month perlod.) this amounts to 100 MT wheat. The balance (400 IIT) should be used for food-for-work projects, designed by the sllu in close cooperation with the local shura and their committees. 


\section{c) other districts}

Gharjestan Reconstruction Councll (GRC), an Afghan NGo recentiy registered by UNOCA, has some projects for waras, Panjao and Jaghor 1. Previously destgned for vulnerable group feeding, they should be redestgned. Only the disabled, orphans and windows should qualify as vulnerable groups. The other categortes should benef $\downarrow$ t from food for work proposals.

d) Others lmplementing partners as Risalat or Khorassan could be Invited to submit proposals.

4. Summary of the lmmediate food dispatches possible if the smu Is approved, and 1 UN staff will be present.

Bamian SHU
Yakawlang
Shetkh Al1/
Parwan:

\begin{abstract}
500 MT wheat w1th two Rubb-Halls 500 MT wheat for the SMU (FFW and school feeding) + $144 \mathrm{MT}$ emergency a1d. Warehouse avallable (800 HT)

Rellef 480 MT wheat + Two Rubb-Halls tents.
\end{abstract}

N.B: The balance from the AVICEN project 18 already committed to Behsud.

UNILOG should be consulted for logistical arrangements. WFP/ARRO recommend dispatches from llazar-1-Sharif as $1 \mathrm{t}$ w1l be cheaper and, one hopes, safer than from the south. Sayed Mansour and Baz llohammed, two prominent commanders loften at odds with each otherl, would need to be involved. 
NNNEX K: Daily wages In Bamian

\begin{tabular}{|c|c|c|c|c|c|}
\hline \multirow{2}{*}{\multicolumn{2}{|c|}{ occupation }} & 1987 & 1988 & 1989 & 1990 \\
\hline & & da1ly wage & dally wage & datly wage & dally wage \\
\hline 1. & Mas on & & & & \\
\hline 2. & Unskilled Labourer & $\begin{array}{l}500 \\
200\end{array}$ & $\begin{array}{l}700 \\
350\end{array}$ & 900 & 2000 \\
\hline 3. & Carpenter & $\begin{array}{l}200 \\
600\end{array}$ & 350 & 450 & 950 \\
\hline 4. & Nan maker & $\begin{array}{l}600 \\
400\end{array}$ & 900 & 1200 & 2500 \\
\hline 5. & Cook & $\begin{array}{l}400 \\
250\end{array}$ & 600 & 1000 & 2000 \\
\hline 6. & Driver & 250 & 450 & 600 & 1000 \\
\hline 7 . & Asst. Driver & 600 & 800 & 1200 & 1500 \\
\hline & Asst. Driver & 300 & 350 & 650 & 700 \\
\hline
\end{tabular}




\section{ANNEX L: Letter from HFP participant to the shura}

To the Islamic Shura In Bamian

1. Food aid 18 an input which can come to support any kind of (Cash, technical advice materials etc.) 2. Food ald is not for sale, although it can be sold on excep-
tional basis after WFP's approval to this effect.

3. Food ald should be used:

- Elther in food-for-work (daily payment for Labour) required

Priority should be given to food-for-work

4. In food-for-work the daily ration 1 s one ser of wheat per
manday of work and rehabilitation authorities to support projects approved
by WFP. Programme report should be sent to ifp regularly. 
ANNEX P: A brief catalogue of the historic sites of Bamian

The following observations are the result of all-too-brief visits to a number of the many historic sites; both Bhuddist and Islamic, on the mission's route. The strategic importance of Bamian has attracted the attention of waves of invaders and travellers right up to the present day, and its monuments have been described and recorded in many texts over the centuries.

Kalu, Bamian: the Caravanserat

This is a good example of a late 19 th century caravanserai, one of a series built by Afghan kings across the country, made of thick mud walls and mud bricks. One of the four corner towers is partly destroyed. It has two courtyards, one with a mosque $(15 \mathrm{~m}$.

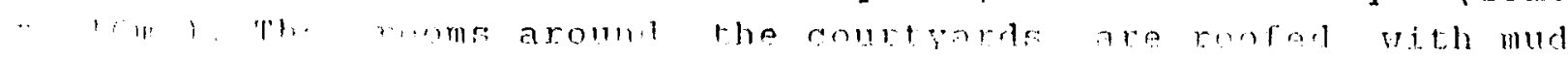
brjok domes and four colomades ate oomplete with arches and vaults.

The location of the caravanserai in the green mountain landscape of Kalu invites its restoration both as a means to provide local work and skills and to see it used as an institution of some kind - a school or training centre.

Shashpul, Bamian: the remains of Zerhak city

This magnificent fortification is located on the red rocky hill overlooking the south easterly entrance to Bamian valley. While its lower main construction is situated more than 100 meters above the river, its crest is at $200 \mathrm{~m}$, or more.

The city has not been systematically studied or excavated. While most of the structures are in ruins, there are more than six domed rooms, or towers, attached to the walls of the lower palace. The thick mud bricks, in two columns (yellow and red) are square in shape. The bricks used in walls are $40 \mathrm{~cm} \times 10 \mathrm{~cm} \times 20$ cm.

The fort is occupied by mujahedin of Harakat-1-Inqelab, who have built some living quarters, covered with timber, in the lower palace and have some watchposts at the crest. They have also installed a gate at the access road, after the original security tower, in order to prevent strangers walking into the city. There is great potential for restoration of the half fallen domes and safeguarding the walls to avold further erosion by snow and rain. 


\section{9}

Shahr-1-Khosak

An Islamic fortified city. The Shekari valley near Ghandak, this fortification is located on a hill that provides views over both ends of the gorges. The walls in shahr-i-Khosak contrast with many other fortifications in Bamian, having high stone foundations that support the thick mud brick walls. The bricks measure $28 \mathrm{~cm} \times 8 \mathrm{~cm}$ on the walls and arches. The roofing of the chambers are completed by beam vaults and domes. There are 3 palaces that reveal double storey construction. The upper floors are now destroyed and only the walls remain, while most of the lower stories have survived natural deterioration. There are small mosque buildings near each one of the palaces or residential complexes. The remains of a canal are also visible; it brought water from Khoshak river up to the fortification and drove a water mill.

The lower palt of the hill also has caves once used for residential purposes.

Today the site is occupied by some villagers who have built residences utilizing the stones and bricks from the historic remains. Mohammed Nasim, a resident of Shahr-i-khosak, has built a residence and has found some written inscriptions. The caves are also userl as stables. The mission met a man who was in process of altering one of the historic constructions as a residence, keeping and rebuilding some parts, which of course would not retain any of their historic significance. A note was sent to local commander asking him to assist in safeguarding the historic sites.

Kakrak: The Buddha

The Buddha figure in Kakrak valley just east of Bamian town is situated on the eastern side of the hill, commanded by some towers that might be the remains of either security posts or a fortification. The Buddha figure is complete, although there are some light bullet marks. There is no sign as to whether this Buddha was repaired in $1970 \mathrm{~s}$ or not. The cave rooms, $1,70 \mathrm{~m}$ in 
diameter, are eight sided and the dome ceiling ( 2.5 meter height) is carefully excavated in the cliffs on the two sides of the Buddha. They are in bad need of repair. Another chamber with a fallen celling bears details of corner arches and some painted frescos on wall that are mud washed. With careful restoration, one might be able to see the old paintings. The ditches above the Buddha provided in early 1970 are now flooded, full of soll brought down from the upper hillside. The area is controlled by Jamiat mujahedin. Vehicles can reach within a 5 minute walk of the site.

The tomb of Khwaja Sabzposh:

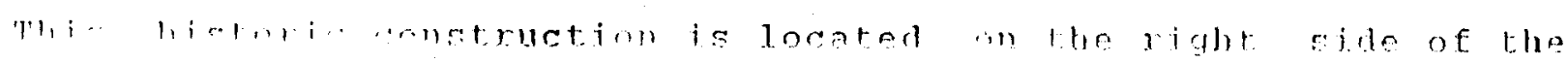

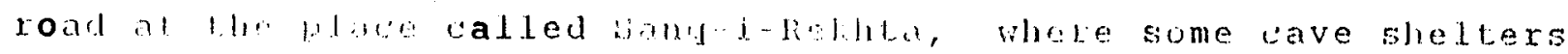
can be seen in the cliff some $100 \mathrm{~m}$ away. The construction is built of $80 \mathrm{~cm}$ thick walls of square shaped mud bricks $130 \mathrm{~cm} \times$ $30 \mathrm{~cm} \times 7 \mathrm{~cm}$ ) and some hard clay walls. The dome and its corner arches are built of burnt bricks of $27 \times 27 \times 4$ cm and the inside measurement is 376 x $386 \mathrm{~cm}$. It might belong to the Ghorid period, as some construction details would suggest, but there is no inscriplion. The construction is not in good repair.

Shahr-1-Gholgula:

The famous Shahr-1-Gholgula, the 15-16th century city of Bamian, has a fantastic location for one can see all five valleys of Bamian. It consists of a hill surrounded by agricultural fields, and commands the whole of Bamian centre. It has survived despite the excavations by farmers (who treasure the soil from the hill as fertilizer). The site was under soviet occupation for 8 years until their withdrawal. Visiting the site today gives one a good 1dea of the nature of soviet presence: their horse stables, watch posts and broken weapons still remain on site. Thousands of empty cartridges and tins of food lie about, many on the hill sides of the Gholgula which are heavily mined; no one dares wander around. It was not lpossible go into the domed chambers on the south western side of the hill. The site 1 s under control and guard of Harakat-i-Islami (Hohseni). 
The Bamian Museum:

Bamian had a small museum, where some antiquities from Bamian were put on exhibition. Haji Abdullah, the former Administrator of the department of Antiquities in Bamian, told the mission that the museum was transferred to Kabul National Museum. A small copy of the Buddha which, apparently was made by Indians as model for repair of the Buddha of Bamian, went into private hands and was apparently on sale for $\$ 20,000$ two years ago.

The caravanserai of Topchi:

A caravanserai dating from $1880 \mathrm{~s}$ is located below the main road at ropchi. It has been bombed several times and its gate is damaged. The rooms with domes and vaults are partly intact. It could be the basis of an excellent restoration project through which technical labour could be trained and employed. The restored construction could be used for institutional functions such as a boarding school, teacher training school and the like.

The Buddhas of Bamian:

The Buddhas are apparently in good condition. Some caves and the hilltop of the cliff had been used by government forces as military posts, leaving the caves black with fire smoke; their sand bags are still around.

Since the capture of Bamian by the mujahedin, the Buddhas have been occupied by different groups. The big, Buddha is under control of Nasr and the small Buddha is under control of Harakat Inqelab. They both guard access the monuments carefully. The mission visited the big Buddha, the caves at its feet, the caves above, and around the head of Buddha. Bullet marks were evident, although there is not too much damage. Some caves that have been used by Government forces are covered with fire smoke and some have had holes drilled into them. There are ten caves that can be considered important for their detail, ceilings and corners. 


\section{2}

The small Buddha appears to be in good condition from a distance. It was not possible to visit the site as Harakat Inqelab banned access. Unofficial reports are that some people have cut the frescos, and dug for antiquities which have then been taken to and sold in Kunda sang (in the area controlled by sayed Mansoor), where they are then taken to Kabul.

The water collecting ditches are partly covered with flooded soil from the hill and need cleaning and repalr. One of the bottom caves of the large Buddha is occupled by Sazman Nasr (by people from Yakawlang) and others by Harakat Ingelab for use as military stores. Some children, who had visited the upper hill, told the mission that the ditches that were built to collect surface water from the top of the Buddhas are now damaged due to artillery shots; water leaks through the holes; other parts of the ditches have been blocked by soll and need cleaning.

other major problems include the many vertical cracks on the surface of the cliff, warning signs that great chunks of the cliffs may collapse. Long term conservation requires stabilisation of the face of the cliff, otherwise most of the remaining caves may eventually fall away.

Some local people said that the sitting Buddha once became the target of mujahedin attack. This story was discounted by Haj1 Abdullah, the former Administrator of Bamian department of antiquities, who still lives in Bamian.

Qasr-1-Kan1shka:

Caves in Tajik village, Folladi. In this side valley of Bamian, there are some caves that bear painted frescos applied on carefully carved regular ceiling designs. It is said that these decorated residences belonged to Kanishka, and thus the place is called as Qasr-1-Kanishka.

Unfortunately only about half the caves remain as the others have fallan rin to goological restruction of the cliff. The cliff is

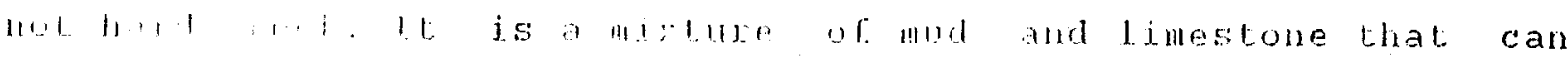
easily be damaged when water penetrates it. 
The caves near to the site are used as shelter and stables for animals. The lower parts of the site of the derorated ceilings are used as outdoor shelter for cattle.

Further west, the mission visited two caves that bore human skulls and bones. It is difficult to say whether these two caves were burial caves or not, but one of the caves is white-washed and has some geometric paintings in red, blue and yellow. The other one was not painted. Both caves have an elevated platform, a size of a single bed, at the inner end. The ceilings are barrel vaulted. One of the cave had a wall (blocking its door), but is now open.

There is a construction on the eastern upper side of the cave complexes, of which only a tower remains which is called Minar-iFoladi. There is no access to $1 \mathrm{t}$.

Yakawlang:

Historically, Yakawlang was part of the province of Takhar and Balkh until the period of Nadir Afshar (1770s). After that Yakawlang became part of Ghor province. In contemporary Afghanistan, Yakawlang became part of the district Daizangi, Kabul province. In 1964, Yakawlang became part of Bamian province. The people (although being Hazara) and their environment much resemble that of the northern provinces of Afghanistan.

It was not possible to visit the -historic sites and the fortification of Chel-Burj, which involves an 8 hours ride each way from Yakawlang. A middle aged man, Mr. Shikh Ahmed, currently responsible for Hezb Wahdat Cultural affairs in Yakawlang, provided the following information: 
Chelburj:

A cultural heritage that belongs to the Kashan Dynasty. Its old name was wukh and is located about $300 \mathrm{~m}$ from the river level. Like the Ghulgula city in Bamian, Chelburj has walls and forty towers on a hill surrounded by valleys. It was destroyed by Genghis Khan. llany antiquities have been found here, especially copper coins with the name 'sherin' inscribed in the Nastaliq style of Farsi letters. Walls and towers remain at half their original height covered chambers survive. The site covers an area of $200 \mathrm{~m} \times 200 \mathrm{~m}$. In the vicinity a village is located with the same name, chelburj, which is the most populated settlement of Yakawlang.

\section{Gurgin:}

A citadel belonging to Ghaznavid era is located 2 hours walking distance eastward from Yakawlang Bazaar. It had securtty towers, but one of them fell down in 1988 due to snow and rain water. Ghaznavid coins in copper and silver have been found there.

The wall on the ridge of Yakawlang:

A wall was built from Balkhab end, passing through the mountains of Band1 Petab, Kotal Howz Shah, Dasht Dewal Bast, Kotal Siabomak and finished at Sang-i-shanda of Behsud. It was built with stone foundations supporting the mud wall, which has deteriorated, and only the foundations, in some places as high as a $180 \mathrm{~cm}$, remain. The stone work seem to be regular and straight.

Barbar:

A military base, and a settlement whose historic name was Gawalian covered a site of $300 \mathrm{~m} \mathrm{~m} 400 \mathrm{~m}$. It has a reservolr for collecting rain and snow water for drinking use. The site bore many Islamic inscriptions in Kuffi, documents in Nuskhi style of lettering and dot-less letters in Farsi and Arabic. The name Khwaja is used often. 


$$
58
$$

Probably only $10 \%$ has remained. The mujahedin had a post there, which was bombed by the government and therefore much of it has been destroyed.

A book on Yakawlang:

Sayed Mohammed Hajl from Lor village of Charde Yakawlang had written an account on Yakawlang. He was educated in Mir Arab Madrassa and died in 1947. His book was apparently taken by the Kabul Government.
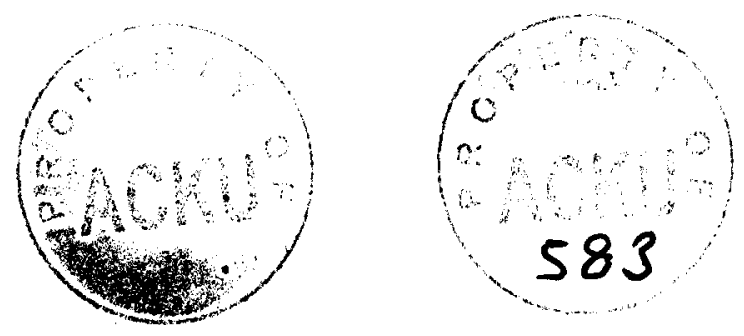